ORIGINAL ARTICLE

\title{
IMPACT OF THE PEGYLATED-INTERFERON AND RIBAVIRIN THERAPY ON THE TREATMENT- RELATED MORTALITY OF PATIENTS WITH CIRRHOSIS DUE TO HEPATITIS C VIRUS
}

\author{
Kelly Fernanda Nomura DRESCH(1), Angelo Alves de MATTOS(1), Cristiane Valle TOVO(1,2), Fernanda Quadros de ONOFRIO(1), \\ Leandro CASAGRANDE(1), Alberi Adolfo FELTRIN(2), Iago Christofoli de BARROS(2) \& Paulo Roberto Lerias de ALMEIDA(2)
}

\begin{abstract}
SUMMARY
Although the protease inhibitors have revolutionized the therapy of chronic hepatitis $\mathrm{C}(\mathrm{CHC})$, the concomitant use of pegylatedinterferon (PEG-IFN) and ribavirin (RBV) is associated to a high rate of adverse effects. In this study, we evaluated the consequences of PEG-IFN and RBV and their relationship with mortality in patients with cirrhosis. METHODS: Medical records of CHC who underwent treatment with PEG-IFN and RBV in a public hospital in Brazil were evaluated. All the patients with cirrhosis were selected, and their clinical and laboratory characteristics, response to treatment, side effects and mortality were evaluated. RESULTS: From the 1,059 patients with CHC, 257 cirrhotic patients were evaluated. Of these, 45 (17.5\%) achieved sustained viral response (SVR). Early discontinuation of therapy occurred in 105 (40.8\%) patients, of which 39 (15.2\%) were due to serious adverse effects. The mortality rate among the 257 cirrhotic patients was 4.3\%, occurring in 06/242 (2.4\%) of the Child-A, and in 05/15 (33.3\%) of the Child-B patients. In conclusion, the treatment of patients with cirrhosis due to HCV with PEG-IFN and RBV shows a low SVR rate and a high mortality, especially in patients with liver dysfunction.
\end{abstract}

KEYWORDS: Chronic hepatitis C; Cirrhosis; Hepatitis C virus; Therapy.

\section{INTRODUCTION}

It is estimated that $3 \%$ of the world's population is infected with hepatitis $\mathrm{C}$ virus (HCV), representing about 170 million people chronically infected and at risk of developing complications resulting from the infection ${ }^{1}$.

We are currently experiencing the era of direct-acting antiviral drugs (DAAs), such as protease inhibitors (PI) that, when added to pegylated interferon (PEG-IFN) and ribavirin (RBV), are capable of achieving significant gains regarding sustained virological response (SVR). On the other hand, the use of these new molecules, despite their advantages, presents new challenges: the appearance of variants with a possible decreased sensitivity to new DAAs, a higher occurrence of adverse effects, drugs interactions, and a significant increase in the total cost of antiviral therapy ${ }^{2}$. The biggest obstacles to the success of treatment with the current triple therapy (first-generation PI) were the frequent, and sometimes severe, adverse effects. Thus, although a discussion about the adverse effects and mortality of dual therapy may seem unfruitful in the PI-era, we understand that it is still relevant, since at the present time some available drugs might be used in combination with PEG-IFN and RBV. It is worth noting that interferon-free therapies are not yet part of our reality.
This study aimed to evaluate the occurrence of adverse effects and mortality in cirrhotic patients due to hepatitis C, treated with PEG-IFN and RBV.

\section{METHODS}

A descriptive, cross-sectional study was performed, in which we analyzed the medical records of all the patients with cirrhosis due to chronic hepatitis $\mathrm{C}$ who underwent treatment with dual therapy (PEG-IFN and RBV). The drugs used were PEG-IFN alpha-2a 180 mcg or PEG-IFN alpha-2b 1,5 mcg/kg, subcutaneously, once a week associated with RBV $15 \mathrm{mg} / \mathrm{kg} /$ day, orally. Patients were monitored by the Administration and Monitoring Center for Injectable Medications (CAMMI) at the Hospital Nossa Senhora da Conceição in Porto Alegre, a tertiary-care public hospital in Southern Brazil, in the period between March 2003 and June 2013.

Among the medical records, only the patients with cirrhosis were selected for analysis. The diagnosis of cirrhosis was defined by clinical, laboratory and/or image evidence, or by liver biopsy when necessary. Patients who were co-infected with the human immunodeficiency virus (HIV) and hepatitis B virus (HBV) were excluded.

(1) Universidade Federal de Ciências da Saúde de Porto Alegre (UFCSPA). Porto Alegre, Brasil.

(2) Hospital Nossa Senhora da Conceição. Porto Alegre, RS, Brasil.

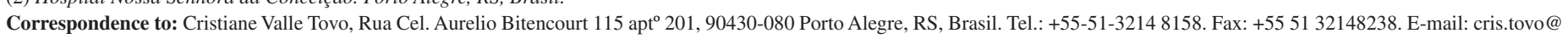
terra.com.br 


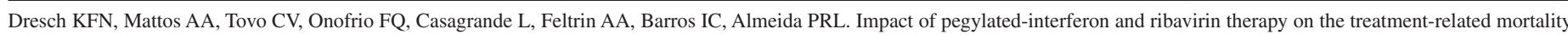
of patients with cirrhosis due to hepatitis $C$ virus. Rev Inst Med Trop Sao Paulo. 2016;58:37.

We assessed each patient's demographic and clinical characteristics (age, gender, weight, previous treatment) as well as pre-treatment laboratorial/ biochemical parameters (hemoglobin levels, white blood cell count, platelet count, prothrombin time, total bilirubin, albumin, and serum creatinine). We also determined the patients' HCV genotype and viral load. Additionally, the Child-Pugh-Turcotte ${ }^{3}$ score and the MELD score - Model for End Stage Liver Disease ${ }^{4}$ were considered, as well as the presence of esophageal varices.

To evaluate the virological response to treatment, we considered as non-responders (NR), patients who did not have a decrease of at least 2 logarithms in the HCV viral load at week 12 of treatment, or who had a detectable viral load at weeks 24 or 48 of treatment. Sustained virological response (SVR) was defined as the maintenance of a nondetectable HCV-RNA, assessed at week 24 of the follow-up, after the completion of treatment.

The early discontinuation of treatment was considered in all nonresponders at week 12 of therapy, as well as in those who interrupted treatment due to serious adverse effects (SAE).

In the assessment of the safety profile of the therapy, we evaluated the reasons for treatment interruption, the need of drug dosage reduction, the occurrence of adverse events, and death.

The SAE were: decompensation of the liver disease, presence of severe infection during treatment, relevant anemia, neutropenia or thrombocytopenia despite reductions in drug dosages and use of erythropoietin (EPO) and/ or filgrastim. Anemia was considered when hemoglobin levels were equal to or below $10 \mathrm{~g} / \mathrm{dL}$, or hemoglobina decreased more than $3 \mathrm{~g} / \mathrm{dL}$ compared to pre-tratament ${ }^{5}$. Neutropenia ${ }^{6}$ was considered when the neutrophil count was equal to or less than 750 cells $/ \mathrm{mm}^{3}$. Three levels of thrombocytopenia were considered: 150,000 to $100,000 / \mathrm{mm}^{3} ; 99,000$ to $51,000 / \mathrm{mm}^{3}$ and equal to or less than $50,000 /$ $\mathrm{mm}^{3}$.

Quantitative data was described as mean, standard deviation, and minimum and maximum values. Categorical data was presented as the total count and percentage. To obtain estimates for the association of selected factors with SVR we used the Odds Ratio (OR) calculated in a logistic regression model. Additionally, in the logistic regression model, a stepwise forward selection was performed to identify the variables that stood out in predicting SVR (all described in Table 2 and 4), according to the classical variables related to SVR and death described in the literature ${ }^{7,8}$. Additionally, a Cox proportional hazard model was designed to obtain hazard ratio estimates (HR) and their respective confidence intervals (CI). The significance level was set at $\alpha=0.05$. Data were analyzed using SPSS, version 22.

\section{RESULTS}

The records of 1,059 patients with chronic liver disease due to HCV were evaluated. Of these, 776 patients without cirrhosis and 26 patients co-infected with HIV were excluded.

The demographic and clinical characteristics of the 257 cirrhotic patients, as well as the laboratory tests results and HCV-related data are shown in Table 1.
Table 1

Evaluated data in cirrhotic patients who underwent therapy with PEG-IFN and RBV

\begin{tabular}{|c|c|}
\hline Variables & Patients \\
\hline Male gender, n (\%) & $143(55.6)$ \\
\hline Age, years & $53.8 \pm 9.3$ \\
\hline Initial Weight, Kg & $75.7 \pm 14.6$ \\
\hline Previous treatment, n (\%) & $96(37.4)$ \\
\hline Hemoglobin, g/dL & $14.1 \pm 1.7$ \\
\hline Leukocytes, count $/ \mathrm{mm}^{3}$ & $5,394 \pm 2,035$ \\
\hline Platelets, count $/ \mathrm{mm}^{3}$ & $120,421 \pm 60,140$ \\
\hline Prothrombin time, $\mathrm{s}$ & $14.4 \pm 3.7$ \\
\hline Total bilirubin, mg/dL & $1.11 \pm 0.68$ \\
\hline Albumin, g/dL & $3.93 \pm 0.60$ \\
\hline Creatinine, $\mathrm{g} / \mathrm{dL}$ & $0.8 \pm 0.2$ \\
\hline \multicolumn{2}{|l|}{ Child Pugh, n (\%) } \\
\hline A & $242(89.4)$ \\
\hline B & $15(10.6)$ \\
\hline MELD & $9.25 \pm 3.1$ \\
\hline Esophageal varices, n (\%) & $68(27.8)$ \\
\hline \multicolumn{2}{|l|}{ Genotype n (\%) $(\mathrm{n}=239)$} \\
\hline 1 & $153(64.0)$ \\
\hline 2 & 07 (2.9) \\
\hline 3 & $79(33.1)$ \\
\hline Viral load $\geq 600,000 \mathrm{IU} / \mathrm{mL}$ & $166(65.1)$ \\
\hline
\end{tabular}

Data are presented as mean \pm standard deviation or total count (percentage). HCV: hepatitis C virus, MELD: Model for Endstage Liver Disease

In assessing the response to the treatment used, 45 (17.5\%) patients had SVR. The variables evaluated for the virological response are shown in Table 2 . In the univariate analysis, the only variable considered significant for virological response was a viral load $<600,000 \mathrm{IU} / \mathrm{mL}$ (OR: 3.71; CI:1.85-7.14; $p<0.001$ ). When the multivariate analysis was performed, a viral load < 600,000 IU/mL (OR: 5.55; CI:2.00-16.66; $p$ $=0.001)$ and a prothrombin time of less than 14 seconds (OR: 3.12 ; CI:1.07-9.09; $p=0.003$ ) were considered significant.

The interruption of treatment occurred in 105 (40.8\%) patients, of whom $60(23.3 \%)$ did not show any virological response at week 12 of treatment, in $39(15.2 \%)$ patients due to the appearance of adverse effects, and in six $(2.3 \%)$ patients because they voluntarily requested to interrupt the treatment. Fifty-four $(21.6 \%)$ patients required a lower dosage of PEG-IFN, and 66 (25.7\%) patients had the RBV dosage reduced due to adverse effects. Among the adverse effects, anemia, neutropenia and thrombocytopenia $\left(<100,000 / \mathrm{mm}^{3}\right)$ stood out, affecting $75 \%, 19.5 \%$ and $65 \%$ of patients, respectively. Regarding the $11(4.3 \%)$ deaths, five occurred as a result of hepatic decompensation, four due to infection, one due to upper gastrointestinal bleeding (rupture of esophageal varices), 


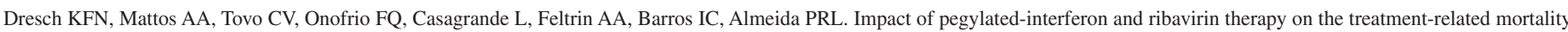
of patients with cirrhosis due to hepatitis $C$ virus. Rev Inst Med Trop Sao Paulo. 2016;58:37.

Table 2

Variables associated with SVR in patients with cirrhosis undergoing therapy with PEG-IFN and RBV

\begin{tabular}{|c|c|c|c|c|c|}
\hline & $\begin{array}{c}\text { SVR }(\%) \\
n=45\end{array}$ & $\begin{array}{c}\text { NR }(\%) \\
n=212\end{array}$ & OR & CI95\% & $p$ \\
\hline Male gender & 55.6 & 55.7 & 1.00 & $0.52-1.90$ & $>0.99$ \\
\hline Age $\geq 65$ & 17.8 & 13.2 & 1.42 & $0.60-3.36$ & 0.47 \\
\hline Weight, $\mathrm{Kg}^{*}$ & $76.0^{\S}$ & $75.0^{\S}$ & 0.99 & $0.97-1.01$ & 0.47 \\
\hline Previous treatment & 51.1 & 34.4 & 1.99 & $1.04-3.81$ & 0.42 \\
\hline Hemoglobin $\geq 10 \mathrm{~g} / \mathrm{dL}$ & 100.0 & 97.6 & - & - & 0.59 \\
\hline Leukocytes, count $/ \mathrm{mm}^{3 *}$ & $5,000^{\S}$ & $5,006^{\S}$ & 1.00 & $1.00-1.00$ & 0.52 \\
\hline Platelets $\geq 100,000 / \mathrm{mm}^{3}$ & 63.4 & 50.7 & 1.68 & $0.84-3.36$ & 0.17 \\
\hline Prothrombin time $<14$ s & 63.7 & 48.5 & 1.89 & $0.89-4.00$ & 0.10 \\
\hline Total Bilirubin $\geq 1 \mathrm{mg} / \mathrm{dL}$ & 44.7 & 49.4 & 0.82 & $0.49-1.67$ & 0.72 \\
\hline Albumin $\geq 3.5 \mathrm{~g} / \mathrm{dL}$ & 88.9 & 81.4 & 1.83 & $0.60-5.57$ & 0.33 \\
\hline Child B & 7.4 & 11.4 & 0.62 & $0.13-2.93$ & 0.73 \\
\hline MELD & 9.0 & 8.0 & 1.03 & $0.89-1.19$ & 0.69 \\
\hline Esophageal varices & 33.3 & 26.5 & 1.38 & $0.69-2.77$ & 0.36 \\
\hline \multicolumn{6}{|l|}{ Genotype (n=239) } \\
\hline 1 & 53.5 & 66.3 & - & & \\
\hline 2 & 7.0 & 2.0 & 4.24 & $0.89-20.20$ & 0.07 \\
\hline 3 & 39.5 & 31.6 & 1.55 & $0.77-3.11$ & 0.22 \\
\hline Viral Load < 600,000 IU/mL & 60.0 & 29.5 & 3.71 & $1.85-7.14$ & $<0.001$ \\
\hline
\end{tabular}

CI: confidence interval; SVR: sustained virological response; NR: non-responders; *odds ratio expressed by unit increase; ${ }^{\S}$ : median.

and one due to a stroke. Table 3 illustrates the safety profile of therapy with PEG-IFN and RBV.

It should be highlighted that of the 11 deaths, six occurred in patients classified as Child-A $(06 / 242 ; 2.4 \%)$ and five in patients classified as Child-B $(05 / 15 ; 33.3 \%)(p<0.001)$.

When factors associated with mortality were evaluated in patients who underwent therapy with PEG-IFN and RBV, the variables that reached significance were (Table 4): liver failure represented by patients classified as Child B (HR: 15.92; CI: 4.80-52.75, $p$ : $<0.001$ ); patients with high scores on the MELD scoring system (HR:1.26; CI:1.08-1.48, $p$ : 0.003); albumin dosage lower than $3.5 \mathrm{~g} / \mathrm{dL}$ (HR: 9.09; CI: 2.56-33.33, $p: 0.001$ ); total bilirubin $\geq 1 \mathrm{mg} / \mathrm{dL}$ (HR: $10.90 ;$ CI: $1.38-86.08 ; p: 0.024)$ and leukocyte count lower than 4,000 cells $/ \mathrm{mm}^{3}$ (HR: 5.25; CI: 1.54$17.96 ; p$ : 0.008$)$. It was not possible to perform the multivariate analysis because of the small number of deaths.

The median follow-up time was 48 weeks. When analyzing the patients' survival in relation to the treatment time, the survival rate at the end of 48 weeks of treatment was $94.4 \%$.

\section{DISCUSSION}

The treatment of chronic hepatitis $\mathrm{C}$ has been rapidly evolving since the advent of new first-generation DAAs such as Telaprevir and Boceprevir ${ }^{9,10,11,12,13}$. A new generation of DAAs has already been approved for use in the United States and Europe ${ }^{14,15}$; however, it is not yet available in Latin America. Added to the fact that treatments using
Table 3

Safety profile of therapy with PEG-IFN and RBV

\begin{tabular}{|c|c|}
\hline Events & Patients, $n=257$ \\
\hline Death & $11(4.3)$ \\
\hline Discontinuation of treatment & $105(40.8)$ \\
\hline Without early virological response & $60(23.3)$ \\
\hline Adverse events & $39(15.2)$ \\
\hline Other reasons: abandonment & $06(2.3)$ \\
\hline PEG IFN Dosage Reduction & $54(21.6)$ \\
\hline RBV Dosage Reduction & $66(25.7)$ \\
\hline \multicolumn{2}{|l|}{ Anemia: } \\
\hline $\mathrm{Hb}<10 \mathrm{~g} / \mathrm{dL}$ or decrease of $>3 \mathrm{~g} / \mathrm{dL}$ & $192(75)$ \\
\hline Use of erythropoietin & $22(8.6)$ \\
\hline Neutrophils $<750 / \mathrm{mm}^{3}$ & $50(19.5)$ \\
\hline Use of filgrastim & $29(11.3)$ \\
\hline \multicolumn{2}{|l|}{ Platelets } \\
\hline 150,000 to $100,000 / \mathrm{mm}^{3}$ & $72(28)$ \\
\hline 99,000 to $51,000 / \mathrm{mm}^{3}$ & $125(49)$ \\
\hline$\leq 50,000 / \mathrm{mm}^{3}$ & $41(16)$ \\
\hline
\end{tabular}

Data presented in total numbers and percentage (\%). PEG IFN: pegylated interferon, $\mathrm{RBV}$ : ribavirin, $\mathrm{Hb}$ : hemoglobin. 
Dresch KFN, Mattos AA, Tovo CV, Onofrio FQ, Casagrande L, Feltrin AA, Barros IC, Almeida PRL. Impact of pegylated-interferon and ribavirin therapy on the treatment-related mortality of patients with cirrhosis due to hepatitis C virus. Rev Inst Med Trop Sao Paulo. 2016;58:37.

Table 4

Variables associated with death in patients who underwent dual HCV therapy

\begin{tabular}{|c|c|c|c|c|c|}
\hline & $\begin{array}{c}\text { Death (\%) } \\
n=11\end{array}$ & $\begin{array}{l}\text { Survival (\%) } \\
\quad \mathrm{n}=\mathbf{2 4 6}\end{array}$ & HR & CI95\% & $p$ \\
\hline Male gender & 45.5 & 56.1 & 0.63 & $0.19-2.07$ & 0.45 \\
\hline Age $\geq 65$ & 9.1 & 14.2 & 0.65 & $0.08-5.08$ & 0.68 \\
\hline Weight, $\mathrm{Kg}^{*}$ & 70.5 & 75.5 & 1.01 & $0.97-1.05$ & 0.81 \\
\hline Previous treatment & 27.3 & 37.8 & 0.58 & $1.15-2.18$ & 0.49 \\
\hline Hemoglobin $\geq 10 \mathrm{~g} / \mathrm{dL}$ & 90.9 & 98.3 & 0.25 & $0.03-1.94$ & 0.19 \\
\hline Leukocytes $<4,000 / \mathrm{mm}^{3}$ & 63.6 & 25.1 & 5.25 & $1.54-17.96$ & 0.008 \\
\hline Platelets $\geq 100,000 / \mathrm{mm}^{3}$ & 40.0 & 53.4 & 0.57 & $0.16-2.02$ & 0.39 \\
\hline Prothrombin time $\geq 14 \mathrm{~s}$ & 60.0 & 48.2 & 1.68 & $0.47-5.92$ & 0.42 \\
\hline Total Bilirubin $\geq 1 \mathrm{mg} / \mathrm{dL}$ & 90.0 & 46.5 & 10.90 & $1.38-86.08$ & 0.024 \\
\hline Albumin $\leq 3.5 \mathrm{~g} / \mathrm{dL}$ & 60.0 & 15.0 & 9.09 & $2.56-33.33$ & 0.001 \\
\hline Creatinine & 0.8 & 0.8 & 1.54 & $0.43-5.44$ & 0.51 \\
\hline Child B & 54.5 & 6.9 & 15.92 & $4.80-52.75$ & $<0.001$ \\
\hline MELD & 12.5 & 8.0 & 1.26 & $1.08-1.48$ & 0.003 \\
\hline Esophageal varices & 30.0 & 27.7 & 1.02 & $0.26-3.93$ & 0.98 \\
\hline \multicolumn{6}{|l|}{ Genotype (n=239) } \\
\hline 1 & 60.0 & 64.2 & - & & \\
\hline 2 & 0.0 & 3.1 & - & & \\
\hline 3 & 40.0 & 32.8 & 1.27 & $0.3-4.52$ & 0.71 \\
\hline $\mathrm{VL} \geq 600,000 \mathrm{IU} / \mathrm{mL}$ & 36.4 & 66.4 & 0.32 & $0.09-1.08$ & 0.065 \\
\hline
\end{tabular}

CI: confidence interval; VL: viral load; *:HR expressed by unit increase

the new DAAs will, at times, also use PEG-IFN+RBV, the high mortality observed in cirrhotic patients with the use of PEG-IFN and RBV in this study is relevant.

A recent French study ${ }^{7}$ that evaluated the treatment of cirrhotic patients with triple therapy (PEG-IFN+RBV+PI) showed that treatment with Telaprevir and Boceprevir presents a lower rate of SVR and low tolerance. Moreover, it showed a significant number of patients with adverse effects, sepsis, and higher mortality rates when compared to the register clinical trials ${ }^{9,13}$, finding that triple therapy should be instituted with caution in this hard-to-treat population ${ }^{16,17}$.

It must be highlighted that although this publication has been the one that alerted the medical community to the risks of HCV therapy, other studies had already called attention to the mortality associated to the dual therapy with PEG-IFN and RBV. However, not all studies assessing cirrhotic patients treated with dual therapy with PEG-IFN and RBV have mentioned mortality during treatment ${ }^{8,18,19,20,21,22}$ although the occurrence of serious adverse effects has been described in up to $40 \%$ of cases ${ }^{16,19,20,21,23,24}$.

Considering that patients selected for clinical trials constitute a subgroup of motivated individuals with fewer comorbidities, which is a better profile than that of patients treated in daily medical practice, it is not surprising that treatment results are often unable to reproduce the successful rates obtained in clinical trials ${ }^{25,26}$.

In the present study, the efficacy of the studied treatment showed SVR in only $17.5 \%$ of patients. In the multivariate analysis, a viral load of less than $600,000 \mathrm{IU} / \mathrm{mL}$ and a prothrombin time of less than 14 seconds reached significance regarding $S V R$.

When 323 patients with chronic liver disease due to genotype $1 \mathrm{HCV}$ treated with PEG-IFN and RBV were assessed, we observed a SVR of $35.3 \%$, and $18.9 \%$ in patients with cirrhosis ${ }^{27}$. More recently, a large multicentric study ${ }^{28}$ with 4,520 genotype 1 patients also observed a lower SVR compared to the register studies, with $32.4 \%$ in those with F3-F4 evaluated jointly. It is worth noting that, in general, in studies evaluating the treatment efficacy, the population of cirrhotic patients only represents a portion of the patients undergoing treatment ${ }^{16,17,19,22}$. The literature has been showing that the higher the degree of fibrosis, the lower the $\mathrm{SVR}^{19,27,29,30}$.

In Fernandez-Rodriguez-APREVIR's ${ }^{31}$ study carried out in a population of cirrhotic patients, a SVR of $30.7 \%$ was found. The independent variables associated with SVR were non-1 genotype, more than $80 \%$ of the planned duration of treatment, high serum level of gamma-glutamyl transpeptidase (GGT), viral load lower than 600,000 $\mathrm{IU} / \mathrm{mL}$, and no signs of portal hypertension on ultrasound. 


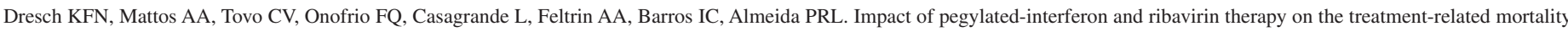
of patients with cirrhosis due to hepatitis C virus. Rev Inst Med Trop Sao Paulo. 2016;58:37.

In the study by Silva et al..$^{32}$, the authors have also included patients with F3 (METAVIR classification), and observed a SVR of $25 \%$. The independent factors associated with SVR were HCV genotype 3, rapid virological response and lower Child score.

In general, studies evaluating SVR in patients with cirrhosis, despite showing a reduced response to therapy, also include patients with advanced fibrosis, without cirrhosis ${ }^{16}$. It is important to highlight that in the present study all the patients had cirrhosis, which explains the lower SVR.

In a systematic review that included 45 studies with chronic hepatitis $\mathrm{C}$ (cirrhotic and non-cirrhotic) patients, the SVR obtained in patients with compensated cirrhosis associated to $\mathrm{HCV}$ genotype 1 varied between 10 to $44 \%$, and in those with genotype 2 or 3 between 33 to $72 \%$. Rapid virological response was considered the most important predictive factor $^{30}$.

In the present study, $40 \%$ of patients had primary treatment discontinuation due to the absence of virological response at week 12 of treatment $(23.3 \%)$, to adverse effects $(15.2 \%)$ or to patients' voluntary request for discontinuation of treatment $(2.3 \%)$. Reduction of PEGIFN dosage was necessary in $21.6 \%$ of participants, and reduction of the RBV dosage occurred in $25.7 \%$ of cases. Although serious adverse events and hematological changes were frequent, the high mortality rate observed $(4.3 \%)$ has called our attention. However, it is noteworthy that this rate was of $2.4 \%$ when only Child A patients were considered. In classical international studies ${ }^{33}$, the discontinuation of treatment due to adverse events occurred in 9 to $14 \%$. Feuerstadt et al. ${ }^{34}$ showed a discontinuation rate of $23 \%$. In two studies performed with cirrhotic patients ${ }^{21,24}$, discontinuation of therapy due to adverse events occurred in $16 \%$ and $29.6 \%$, respectively. However, there are studies ${ }^{19,21}$ that showed no significant differences of adverse effects in patients with and without cirrhosis.

SAE leading to discontinuation of treatment were observed in $15.2 \%$ of cases in the present study, whereas in the literature, SAE have been described in up to $40 \%$ of patients with compensated cirrhosis ${ }^{16,18,19,20,21,24}$.

The mortality described in some studies that jointly assessed patients with F3 and F4 treated with PEG-IFN and RBV varied between $0.3 \%$ and $1.6 \%{ }^{17,28}$. However, such studies present the data related to general mortality, without categorization of mortality according to the degree of fibrosis (F3 or F4).

It has already been demonstrated that serious complications are associated with the treatment in patients with decompensated cirrhosis or Child-Pugh B-C in up to $68 \% \%^{8,24,35,36,37,38,39}$ and mortality in up to $7.6 \%$ of patients ${ }^{8,37}$. In the present study, despite the small number of treated patients, the observed mortality among Child B patients was $33.3 \%$, emphasizing that poor performance during treatment is related to the severity of the liver disease (class B of Child score and increase in MELD score), a serum albumin level of less than $3.5 \mathrm{~g} / \mathrm{dL}$, a total bilirubin level higher than $1 \mathrm{mg} / \mathrm{dL}$ and a leukocyte count lower than 4,000 cells $/ \mathrm{mm}^{3}$. In the studies that assessed mortality, some did not evaluate related factors $^{16,17,37}$, while the Child-C score and neutrophil count below 900/ $\mathrm{mm}^{3}$ were independent predictive factors in the study by Iacobellis $e t$ $a l .{ }^{8}$ On the other hand, some classical variables related to prognosis as creatinine and protrombin time were not statistically significant, possibly due to the small number of deaths.

In conclusion, although the treatment provides an opportunity to eradicate $\mathrm{HCV}$ infection in patients with cirrhosis, thus preventing further progression of the disease $\mathrm{e}^{40,41}$, it can also cause serious adverse events and mortality. When treating this population, a careful evaluation of cirrhotic patients before treatment and a rigorous monitoring of serious adverse events during treatment are indicated. Therefore, whilst the therapy with new DAAs is not fully established, it is important that clinicians pay attention to the adverse effects of therapy with PEG-IFN and RBV.

\section{REFERENCES}

1. Lee SS, Bain VG, Peltekian K, Krajden M, Yoshida EM, Deschenes M, et al. Treating chronic hepatitis $\mathrm{C}$ with peguilated interferon alfa-2a $(40 \mathrm{KD})$ and ribavirin in clinical practice. Aliment Pharmacol Ther. 2006;23:397-408.

2. Pascale A, Serfaty L. Triple therapy with first generation HCV protease inhibitors: lead-in or no lead-in phase? J Hepatol. 2013;58:391-4.

3. Pugh RN, Murray-Lyon IM, Dawson JL, Pietroni MC, Williams R. Transection of the oesophagus for bleeding oesophageal varices. Br J Surg. 1973;60:646-9.

4. Manns MP, McHutchinson JG, Gordon SC, Rustgi VK, Shiffman M, Reindollar $\mathrm{R}$, et al. Peginterferon alfa- $2 \mathrm{~b}$ plus ribavirin compared with interferon alfa- $2 \mathrm{~b}$ plus ribavirin for initial treatment of chronic hepatites $\mathrm{C}$ : a randomised trial. Lancet. 2001;358:958-65.

5. Sherman M, Cohen L, Cooper MA, Elkashab M, Feinman V, Fletcher D, et al. Clinical recommendations for the use of recombinant human erythropoietin in patients with hepatitis C virus being treated with ribavirin. Can J Gastroenterol. 2006;20:479-85.

6. Tandon P, Doucette K, Fassbender K, Vandermeer B, Durec T, Dryden DM Granulocyte colony-stimulating factor for hepatitis $\mathrm{C}$ therapy-associated neutropenia: systematic review and economic evaluation. J Viral Hepat. 2011;18:e381-93.

7. Iacobellis A, Siciliano M, Perri F, Annicchiarico BE, Leandro G, Caruso N, et al. Peginterferon alfa- $2 b$ and ribavirin in patients with hepatites $C$ vírus and descompensated cirrhosis: a controlled study. J Hepatol. 2007;46:206-12.

8. Jacobson IM, McHutchison JG, Dusheiko G, Di Bisceglie AM, Reddy KR, Bzowej $\mathrm{NH}$, et al. Telaprevir for previously untreated chronic hepatitis $\mathrm{C}$ virus infection. $\mathrm{N}$ Engl J Med. 2011;364:2405-16.

9. Bacon BR, Gordon SC, Lawitz E, Marcellin P, Vierling JM, Zeuzem S, et al Boceprevir for previously treated chronic HCV genotype 1 infection. N Engl J Med. 2011;364:1207-17.

10. Lavanchy D. The global burden of hepatites C. Liver Int. 2009;29 Suppl 1:74-81.

11. Poordad F, McCone J Jr, Bacon BR, Bruno S, Manns MP, Sulkowski MS, et al. Boceprevir for untreated chronic HCV genotype 1 infection. N Engl J Med. 2011;364:1195-206.

12. Sherman KE, Flamm SL, Afdhal NH, Nelson DR, Sulkowski MS, Everson GT, et al. Response-guided telaprevir combination treatment for hepatitis $\mathrm{C}$ virus infection. $\mathrm{N}$ Engl J Med. 2011;365:1014-24.

13. Zeuzem S, Andreone P, Pol S, Lawitz E, Diago M, Roberts S, et al. REALIZE Study Team. Telaprevir for retreatment of HCV infection. N Engl J Med 2011;364:2417-28.

14. American Association for Study of Liver Diseases. HCV guidance: recommendations for testing, managing, and treating hepatitis C. [cited 2015 Nov 16]. Available from: http://www.hcvguidelines.org. 
Dresch KFN, Mattos AA, Tovo CV, Onofrio FQ, Casagrande L, Feltrin AA, Barros IC, Almeida PRL. Impact of pegylated-interferon and ribavirin therapy on the treatment-related mortality of patients with cirrhosis due to hepatitis C virus. Rev Inst Med Trop Sao Paulo. 2016;58:37.

15. European Association for the Study of the Liver. EASL recommendations on treatment of hepatitis C 2014. J Hepatol. 2015;61:373-95.

16. Bourlière M, Ouzan D, Rosenheim M, Doffoël M, Marcellin P, Pawlotsky JM, et al. Pegylated interferon- $\alpha 2$ a plus ribavirin for chronic hepatitis $\mathrm{C}$ in a real-life setting: the Hepatys French cohort (2003-2007). Antivir Ther. 2012;17:101-10.

17. Hézode C, Fontaine H, Dorival C, Larrey D, Zoulim F, Canva V, et al. Triple therapy in treatment-experienced patients with HCV-cirrhosis in a multicentre cohort of the French Early Acess Programme (ANRS CO20-CUPIC) - NCTC01514890. J Hepatol. 2013;59:434-41.

18. Annicchiarico BE, Siciliano M, Avolio AW, Caracciolo G, Gasbarrini A, Agnes $\mathrm{S}$, et al. Treatment of chronic hepatitis $\mathrm{C}$ virus infection with pegylated interferon and ribavirin in cirrhotic patients awaiting liver transplantation. Transplant Proc. 2008;40:1918-20

19. Bruno S, Shiffman ML, Roberts SK, Gane EJ, Messinger D, Hadziyannis SJ, et al. Efficacy and safety of peginterferon alfa-2a (40 KD) plus ribavirin in hepatitis C patients with advanced fibrosis and cirrhosis. Hepatology. 2010;51:388-97.

20. Di Marco V, Almasio PL, Ferraro D, Calvaruso V, Alaimo G, Peralta S, et al. Peginterferon alone or combined with ribavirin in $\mathrm{HCV}$ cirrhosis with portal hypertension: a randomized controlled trial. J Hepatol. 2007;47:484-91.

21. Fried MW, Shiffman ML, Reddy KR, Smith C, Marinos G, Gonçales FL Jr, et al. Peginterferon alfa-2a plus ribavirin for chronic hepatitis $\mathrm{C}$ virus infection. N Eng $\mathrm{J}$ Med. 2002;347:975-82.

22. Vezali E, Aghemo A, Colombo M. A review of the treatment of chronic hepatitis C virus infection in cirrhosis. Clin Ther. 2010;32:2117-38.

23. Braks RE, Ganne-Carrie N, Fontaine H, Paries J, Grando-Lemaire V, Beaugrand M, et al. Effect of sustained virological response on long-term clinical outcome in 113 patients with compensated hepatitis C-related cirrhosis treated by interferon alpha and ribavirin. World J Gastroenterol. 2007;13:5648-53.

24. Helbling B, Jochum W, Stamenic I, Knöpfli M, Cerny A, Borovicka J, et al. HCVrelated advanced fibrosis/cirrhosis: randomized controlled trial of pegylated interferon alpha-2a and ribavirin. J Viral Hepat. 2006;13:762-9.

25. Malinchoc M, Kamath PS, Gordon FD, Peine CJ, Rank J, ter Borg PC. A model to predict poor survival in patients undergoing transjugular intrahepatic portosystemic shunts. Hepatology. 2000;31:864-71.

26. de Mattos AZ, de Almeida PR, Tovo CV, de Mattos AA. Pegylated interferon and ribavirin in real life: efficacy versus effectiveness. Hepatology. 2010;52:1867.

27. de Almeida PR, de Mattos AA, Amaral KM, Feltrin AA, Zamin P, Tovo CV, et al. Treatment of hepatitis $\mathrm{C}$ with peginterferon and ribavirin in a public health program. Hepatogastroenterology. 2009;56:223-6.

28. Marcellin P, Cheinquer H, Curescu M, Dusheiko GM, Ferenci P, Horban A, et al. High sustained virologic response rates in rapid virologic response patients in the large real-world PROPHESYS cohort confirm results from randomized clinical trials. Hepatology. 2012;56:2039-50.
29. Aghemo A, Rumi MG, Monico S, Prati GM, D'Ambrosio R, Donato MF, et al. The pattern of pegylated interferon-alpha2b and ribavirin treatment failure in cirrhotic patients depends on hepatitis C virus genotype. Antivir Ther. 2009;14:577-84.

30. Xu Y, Qi W, Wang X, Zhao P, Zhang Y, Zhang Q, et al. Pegylated interferon $\alpha$-2a plus ribavirin for decompensated hepatitis $\mathrm{C}$ virus-related cirrhosis: relationship between efficacy and cumulative dose. Liver Int. 2014;34:1522-31.

31. Fernández-Rodríguez CM, Alonso S, Martinez SM, Forns X, Sanchez-Tapias JM, Rincón D, et al. Peginterferon plus ribavirin and sustained virological response in HCV-related cirrhosis: outcomes and factors predicting response. Am J Gastroenterol. 2010;105:2164-72

32. Silva GF, Villela-Nogueira CA, Mello CE, Soares EC, Coelho HS, Ferreira PR, et al. Peginterferon plus ribavirin and sustained virological response rate in HCV-related advanced fibrosis: a real life study. Braz J Infect Dis. 2014;18:48-52.

33. Giannini EG, Basso M, Savarino V, Picciotto A. Predictive value of on-treatment response during full-dose antiviral therapy of patients with hepatitis $\mathrm{C}$ virus cirrhosis and portal hypertension. J Intern Med. 2009;266:537-46.

34. Feuerstadt P, Bunim AL, Garcia H, Karlitz JJ, Massoumi H, Thosani AJ, et al Effectiveness of hepatites $\mathrm{C}$ treatment with pegylated interferon and ribavirin in urban minority patients. Hepatology. 2010;51:1137-43.

35. Carrión JA, Martínez-Bauer E, Crespo G, Ramírez S, Pérez-del-Pulgar S, GarcíaValdecasas JC, et al. Antiviral therapy increases the risk of bacterial infections in HCV-infected cirrhotic patients awaiting liver transplantation: a retrospective study. J Hepatol. 2009;50:719-28.

36. D'Amico G, Garcia-Tsao G, Pagliaro L. Natural history and prognostic indicators of survival in cirrhosis: a systematic review of 118 studies. J Hepatol. 2006;44:217-31.

37. Everson GT, Trotter J, Forman L, Kugelmas M, Halprin A, Fey B, et al. Treatment of advanced hepatitis $\mathrm{C}$ with a low accelerating dosage regimen of antiviral therapy. Hepatology. 2005;42:255-62.

38. Tekin F, Gunsar F, Karasu Z, Akarca U, Ersoz G. Safety, tolerability, and efficacy of pegylated-interferon alfa-2a plus ribavirin in $\mathrm{HCV}$-related decompensated cirrhotics. Aliment Pharmacol Ther. 2008;27:1081-5.

39. Veldt BJ, Heathcote EJ, Wedemeyer H, Reichen J, Hofmann WP, Zeuzem S, et al. Sustained virologic response and clinical outcomes in patients with chronic hepatitis C and advanced fibrosis. Ann Intern Med. 2007;147:677-84.

40. Cammà $\mathrm{C}$, Giunta $\mathrm{M}$, Andreone $\mathrm{P}$, Craxi $\mathrm{A}$. A interferon and prevention of hepatocellular carcinoma in viral cirrhosis: an evidence-based approach. J Hepatol. 2001;34:593-602.

41. Zhang CH, Xu GL, Jia WD, Li JS, Ma JL, Ge YS. Effects of interferon treatment on development and progression of hepatocellular carcinoma in patients with chronic vírus infection: a meta-analysis of randomized controlled trials. Int J Cancer 2011;129:1254-64

Received:17 May 2015

Accepted: 17 November 2015 